\title{
Imaging of Fault and Fracture Controls in the Arbuckle-Simpson Aquifer, Southern Oklahoma, USA, through Electrical Resistivity Sounding and Tomography Methods
}

\author{
Kumar Ramachandran, ${ }^{1}$ Bryan Tapp, ${ }^{1}$ Tayler Rigsby, ${ }^{1,2}$ and Erin Lewallen ${ }^{1,3}$ \\ ${ }^{1}$ Department of Geosciences, The University of Tulsa, Tulsa, OK 74104-9700, USA \\ ${ }^{2}$ Colorado School of Mines, CO 80401-1893, USA \\ ${ }^{3}$ Chevron Corporation, Houston, TX 77002, USA
}

Correspondence should be addressed to Kumar Ramachandran, kr@utulsa.edu

Received 8 August 2011; Accepted 19 December 2011

Academic Editor: Michael S. Zhdanov

Copyright ( $) 2012$ Kumar Ramachandran et al. This is an open access article distributed under the Creative Commons Attribution License, which permits unrestricted use, distribution, and reproduction in any medium, provided the original work is properly cited.

\begin{abstract}
Arbuckle-Simpson aquifer in southern Oklahoma, USA, is a major source of water for industrial and municipal use. It is also a major source for spring-fed streams in the area. As part of an ongoing study to map and characterize the Arbuckle-Simpson aquifer, an electrical resistivity tomography (ERT) study and electrical resistivity sounding studies were conducted in Johnston County, Oklahoma, USA, to map the subsurface of a small area of the carbonate aquifer. The main aim of the study was to obtain constraints on the location of near surface faults and fractures and how they control groundwater flow in the study area. The interpreted resistivity section along an N-S profile indicates that the water table in the region is deepening to the south and probably bounded in the north by a south dipping fault. Inverse modeling of 2D electrical resistivity tomography (ERT) data acquired at two adjacent locations within the study area indicate shallow, fractured Arbuckle group rocks saturated with water adjacent to dry rocks. From electrical resistivity mapping results, it is inferred that the Mill Creek block in the Arbuckle-Simpson aquifer is an isolated system, interacting with the northern segment of a silicate-based aquifer through dissolution faults and fractures.
\end{abstract}

\section{Introduction}

The Arbuckle-Simpson aquifer located near Pilot Springs and the town of Mill Creek, Johnston County, Oklahoma, USA (Figure 1), is a highly fractured carbonate aquifer. This aquifer serves as a primary water source for around 39,000 residents of the surrounding areas.

Conservation of the Arbuckle-Simpson aquifer in southcentral Oklahoma has been a recent concern. Citizens for the Protection of the Arbuckle-Simpson Aquifer (CPASA) have made efforts to protect against the depletion of the aquifer and its natural springs and waterways as well as protection against pollution and waste. CPASA has concerns about a quarry north of Mill Creek and its impacts to the aquifer as well as Pennington Creek and Mill Creek. The mine will quarry limestone and other materials and will cross a tributary of Mill Creek and Pennington Creek. The mine has already penetrated the water table at 15 to 44 feet beneath the surface and the mining company has proposed to produce 1.5 million gallons of water a day for mining use.

The Cambro-Ordovician units that comprise the aquifer are exposed in 500 square miles of outcrop area that serves as the recharge for the aquifer. This study is focused on the Mill Creek Block of Johnston County, Oklahoma, USA (Figure 1(a)). Two major faults (F1 and F2 in Figure 1(b)) bound the northern and southern boundaries of the Mill Creek block of the Arbuckle-Simpson aquifer.

Electrical techniques have been extensively used for mapping groundwater due to the correlation that generally exists between electrical properties of subsurface rocks and their fluid content [1-5]. Application of electrical techniques for siting wells and boreholes in crystalline basement aquifers 


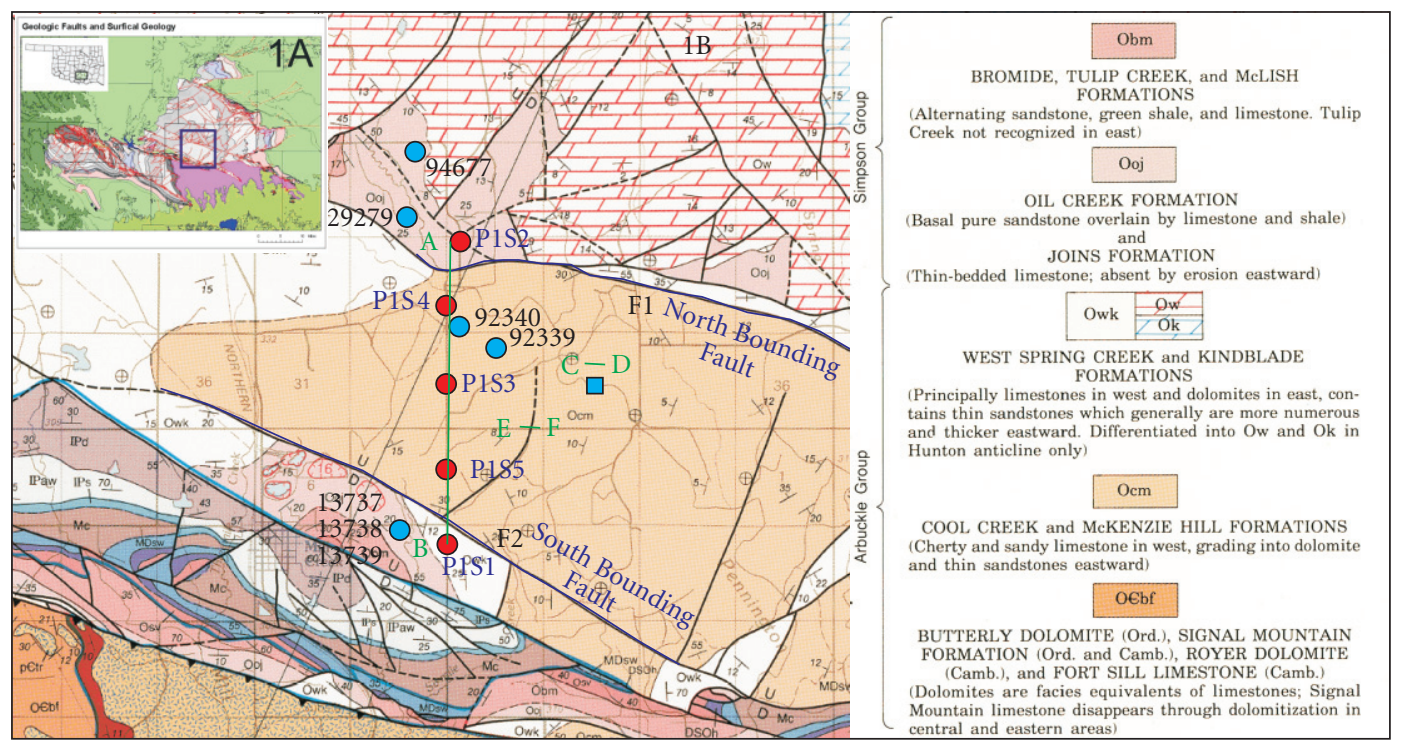

Figure 1: (a) Geographic location of the study area in Oklahoma. (b) Fault structure map of the Mill Creek block, Arbuckle-Simpson aquifer (From [13]). Line A-B represents the N-S sounding profile. CD and EF represent the electrical resistivity tomography profile locations. Red dots indicate the locations where electrical resistivity sounding data were collected. Faults F1 and F2 are imaged in the subsurface using electrical resistivity method to understand how they control ground water flow in the region. Well locations from which depth to groundwater level were obtained are shown by blue dots along with well numbers. Blue square indicates the location of Pilot Springs.

throughout sub-Saharan Africa has been discussed by Beeson and Jones [6], Olayinka and Barker [7], Hazell et al. [8, 9], Barker [10], and Carruthers and Smith [11]. Advances have led to developments in electrical techniques that have opened up the possibility of conducting true $2 \mathrm{D}$ and $3 \mathrm{D}$ geoelectric surveys [12].

\section{Hydrogeology of the Study Area}

The stratigraphy of the aquifer-bearing rocks that outcrop in the Arbuckle Mountains (after [14]) is given in Figure 2. The Arbuckle-Simpson aquifer occurs within three major rock units of Upper Cambrian to Middle Ordovician age: the Simpson, Arbuckle, and Timbered Hills Groups (Figure 3). Data from wells located in the area indicate that the aquifer contains two hydrostratigraphic units: (a) the carbonates of the Arbuckle Group and (b) sandstones of the Simpson Group. The term Arbuckle aquifer is applied to any preSimpson sources of water hosted in limestone or dolomitic limestone. As a result, the aquifer spans strata of the Arbuckle and Timbered Hills Groups in Cool Creek and McKenzie Hill Formations $(\mathrm{Ocm})$ and West Spring Creek and Kindblade Formations (Owk and Ow). The Arbuckle Group, which comprises the major portion of the aquifer, consist of a thick sequence of carbonate rocks (limestone and dolomite) with minor layers of sandstone and shale. The Arbuckle Group ranges in thickness from 6,700 feet in the western portion of the aquifer to less than 4,000 feet in the eastern portion. Water is obtained from cavities, solution channels, fractures, and intercrystalline porosity present in the limestone and dolomite rocks. The Timbered Hills Group crops out in small areas within the study area and consists of up to 700 feet of limestone, dolomite, and sandstone. The Timbered Hills is believed to be in hydrologic connection with the Arbuckle Group and is considered part of the ArbuckleSimpson aquifer.

The Simpson Group is the youngest, uppermost geologic unit of the aquifer and is comprised of layers of sandstone, limestone and dolomite, and some shale. Water in the Simpson Group is obtained primarily from pore spaces between the sand grains in the sandstones. The Simpson aquifer coincides with the lithostratigraphic Simpson Group and includes all water-bearing strata within it. Water-bearing sandstones of the Simpson Group occur in the Bromide, Tulip Creek, McLish (Obm), and Oil Creek formations (Ooj). About two-thirds of the Arbuckle-Simpson aquifer consists of carbonate rocks (limestones and dolomites), which are soluble. Infiltrating water slowly dissolves the rock, leading to the formation of solution channels and cavities along bedding planes, fractures, and faults. Karst (solution) features, such as sinkholes and caverns, have developed in some areas of the aquifer. The Arbuckle-Simpson aquifer is charged primarily by infiltration of water from precipitation on the outcrop area. Most of the water discharges naturally to streams, rivers, and springs. Presently, only a small portion discharges artificially through pumping and flowing wells. In this region, groundwater flows from topographically high areas to low areas, where it discharges to springs and streams.

Fairchild et al. [15] describe the Arbuckle Group specifically as having zero or only little intergranular porosity; porosity and permeability in these formations are instead due to fractures, joints, and solution features. Scheirer and Alegra [16] analyzed outcrop samples in the laboratory yielding porosity values of $5 \%$ for the Simpson Group, 


\begin{tabular}{|c|c|c|c|c|}
\hline System & \multicolumn{4}{|c|}{ Group and formation } \\
\hline \multirow{3}{*}{ 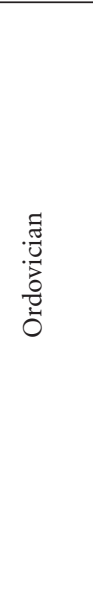 } & 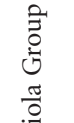 & \multicolumn{3}{|l|}{$\begin{array}{l}\text { Fernvale Formation } \\
\text { Viola Springs Formation }\end{array}$} \\
\hline & 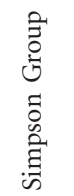 & $\left.\begin{array}{l}\text { Bromide Formation } \\
\text { Tulip Creek Formation } \\
\text { McLish Formation }\end{array}\right\}$ & $\begin{array}{l}\text { Obm } \\
\text { Ooj }\end{array}$ & 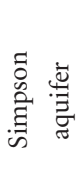 \\
\hline & 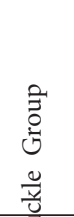 & $\left.\begin{array}{l}\text { West Spring Creek Format } \\
\text { Kindblade Formation } \\
\text { Cool Creek Formation } \\
\text { McKenie Hill Formation }\end{array}\right\}$ & $\begin{array}{l}\text { tion }\} \text { Owk } \\
\text { Ocm }\end{array}$ & 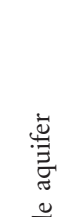 \\
\hline \multirow{3}{*}{ 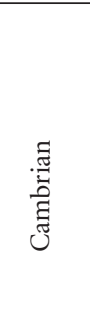 } & 旁 & $\begin{array}{l}\text { Signal mountain formatior } \\
\text { Royer dolomite } \\
\text { Fort Sill limestone }\end{array}$ & & 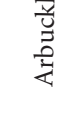 \\
\hline & 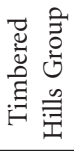 & \multicolumn{2}{|l|}{$\begin{array}{l}\text { Honey Creek limestone } \\
\text { Reagan sandstone }\end{array}$} & \\
\hline & \multicolumn{4}{|c|}{ Colbert rhyolite } \\
\hline
\end{tabular}

FIgURE 2: Stratigraphic nomenclature for the pre-Sylvan Ordovician and Cambrian rocks that outcrop in the Arbuckle Mountains. Positions of the Arbuckle and Simpson aquifers are shown on the stratigraphic column (after [14]).

based on the average porosity of six samples, and $4 \%$ for the Arbuckle Group, based on the average porosity of ten samples. Oil Creek and McLish sandstones are widely distributed in the area and represent the Simpson aquifer properties. Porosity of Oil Creek sandstone and McLish sandstone measured from well logs average about 20\% [17].

\section{Electrical Resistivity Surveys}

To investigate the fault structure and fractures present in the Mill Creek block and to evaluate the controls exerted by them on local ground water hydrology, electrical resistivity soundings were conducted along an NS profile. The interpretation of this data has resulted in a geological crosssection for the Mill Creek block of the Arbuckle-Simpson aquifer. Electrical resistivity tomography (ERT) studies were conducted at two locations (Figure 1) near Pilot Springs in the Mill Creek block. Wenner and dipole-dipole ERT data were collected at both the locations.

3.1. Resistivity Sounding: 1D. Electrical resistivity sounding was performed and five sets of measurements (Figure 1(b)) were collected along a North-South profile to identify the presence of faults and depths to the groundwater table. The ground measurements were separated by approximately $2 \mathrm{~km}$.
Soundings P1S1 and P1S2 were performed using a Wenner array configuration, while soundings P1S3, P1S4, and P1S5, used a Schlumberger array configuration. Data were analyzed by curve matching techniques [18] and inverse modeling using IPI2win public domain software, created and published by Moscow State University. Inversion models and modeled layer resistivities and thicknesses are given in Figure 4.

3.2. Electrical Resistivity Tomography Studies. Electrical resistivity tomography (ERT) studies were conducted at two locations (Figure 1) in the Mill Creek block close to Pilot Springs (Figure 5). Water emerging from Pilot Springs flows into Pennington Creek. The purpose of electrical resistivity imaging at this location was to identify the water source for Pilot Springs [19]. Water from Pilot Springs flows into Pennington Creek (Figure 5). Wenner and dipole-dipole ERT data were collected at this location and at another location south of Pilot Springs (Figure 1(b)). The data was collected using twenty-eight electrodes with five-meter electrode spacing for a total profile length of $135 \mathrm{~m}$. The electrode spacing for the various survey configurations were designed prior to the survey and the data were collected using automatic switching circuitry instrument/electrode system. The dipole-dipole ERT survey resulted in 235 data points and Wenner ERT survey resulted in 135 data points. 


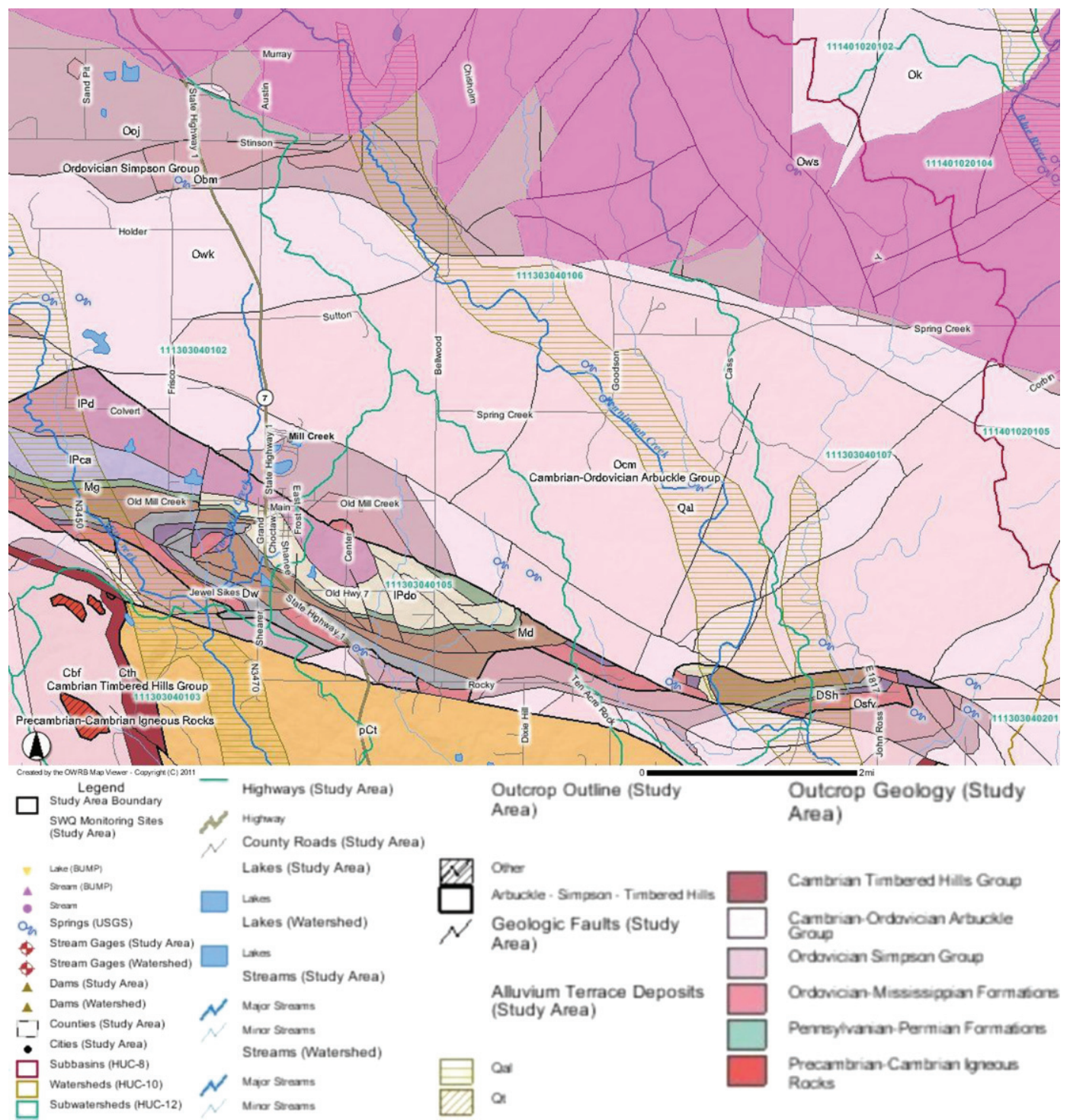

FIgURE 3: Hydrogeology map near Mill Creek Block of Arbuckle-Simpson aquifer.

\section{Data Interpretation}

4.1. 1D Resistivity Sounding Results. A comparison of the models for Soundings P1S2 and P1S4 are of particular interest in this study. These soundings are separated by the northern bounding fault F1 of the Mill Creek block, defining the boundary between the Oil Creek and Joins Formation (Simpson Group) to the north and the Cool Creek and McKenzie Hill Formation (Arbuckle Group) to the south (Figure 4). The relationship between the resistivity properties and depths at these two soundings aid us in understanding how this fault probably controls the aquifer in this area. The drop in resistivity between the second and third layers in both soundings is interpreted as the interface between the dry overburden rocks and the underlying aquifer. The relative position of this interface between these soundings is significant in determining how groundwater flow may be affected by the presence of the northern fault F1 between them. For these two soundings, the depth of the inferred water-saturated layer increases toward the south, and this pattern holds true for Sounding P1S3 as well. This is significant, because it allows for an interpretation in which the northern-bounding fault itself, passing between these two soundings, is the cause of this deepening of the watersaturated layer, and may define the interface between the high-resistivity second layer and the low-resistivity third layer (Figure 6). Such an interpretation is consistent with a southward-dipping thrust model for the northern fault.

Sounding P1S5, like Sounding P1S4, is best fit to a fourlayer subsurface model. The resistivity layers follow the same general pattern as those observed in the three soundings to the north; the second layer is characterized by a relatively high resistivity of 1000-1200 $\Omega$-m, likely dry rock, overlying a low-resistivity second layer of $40-55 \Omega-\mathrm{m}$, interpreted as the top of the aquifer. However, below this low-resistivity zone at a depth of at least $20 \mathrm{~m}$, a fourth layer of exceptionally 


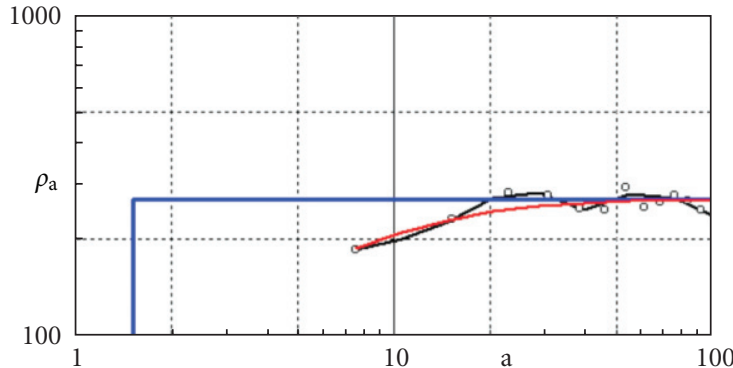

(a)

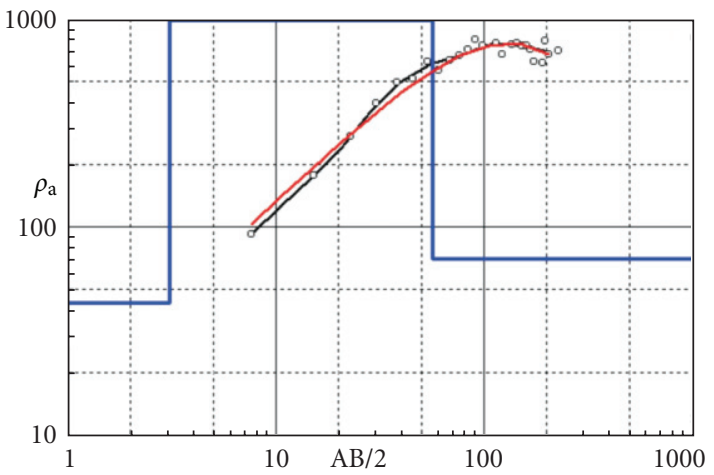

(c)

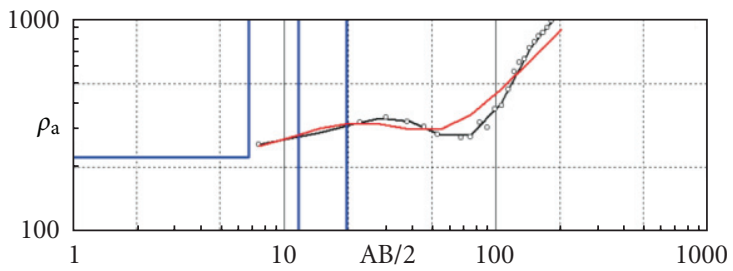

(e)

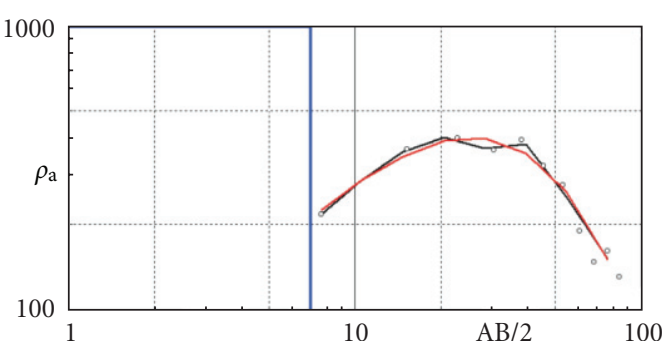

(b)

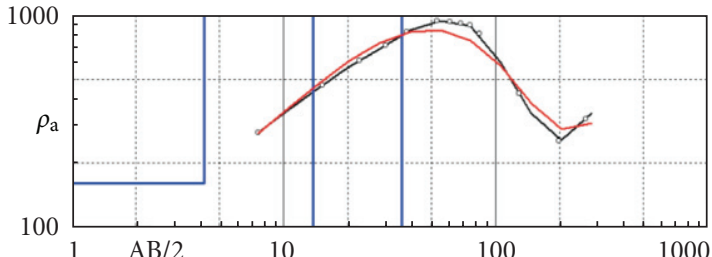

(d)

\begin{tabular}{|l|l|l|}
\hline \multicolumn{3}{|l|}{ Resistivity and depth to base of $h_{n}$} \\
\hline P1S1 & $\begin{array}{l}\rho_{1}=80 \Omega \mathrm{m} \\
\rho_{2}=240-270 \Omega \mathrm{m}\end{array}$ & $h_{1}=1.5 \mathrm{~m}$ \\
\hline \multirow{2}{*}{ P1S2 } & $\begin{array}{l}\rho_{1}=20-25 \Omega \mathrm{m} \\
\rho_{2}=800-1900 \Omega \mathrm{m} \\
\\
\rho_{3}=25-30 \Omega \mathrm{m}\end{array}$ & $\begin{array}{l}h_{1}=0.5-1 \mathrm{~m} \\
h_{2}=7-14 \mathrm{~m}\end{array}$ \\
\hline \multirow{2}{*}{ P1S3 } & $\rho_{1}=40-45 \Omega \mathrm{m}$ & $h_{1}=3-4 \mathrm{~m}$ \\
& $\rho_{2}=2100-5000 \Omega \mathrm{m}$ & $h_{2}=35-55 \mathrm{~m}$ \\
& $\rho_{3}=70 \Omega \mathrm{m}$ & \\
\hline \multirow{2}{*}{ P1S4 } & $\rho_{1}=70-160 \Omega \mathrm{m}$ & $h_{1}=3-4 \mathrm{~m}$ \\
& $\rho_{2}=1400-5700 \Omega \mathrm{m}$ & $h_{2}=35-55 \mathrm{~m}$ \\
& $\rho_{3}=25-55 \Omega \mathrm{m}$ & $h_{3}=36-70 \mathrm{~m}$ \\
& $\rho_{4}=10000 \Omega \mathrm{m}$ & \\
\hline \multirow{2}{*}{ P1S5 } & $\rho_{1}=255 \Omega \mathrm{m}$ & $h_{1}=6-7 \mathrm{~m}$ \\
& $\rho_{2}=1000-1200 \Omega \mathrm{m}$ & $h_{2}=11-12 \mathrm{~m}$ \\
& $\rho_{3}=40-55 \Omega \mathrm{m}$ & $h_{3}=20 \mathrm{~m}$ \\
& $\rho_{4}=10000 \Omega \mathrm{m}$ & \\
\hline
\end{tabular}

(f)

Figure 4: Inversion models for soundings 1 to 5 are shown in (a) to (e). (a) Sounding P1S1, (b) Sounding P1S2, (c) Sounding P1S3, (d) Sounding P1S4, and (e) Sounding P1S5. $X$-axis represents distance in meters and $Y$-axis represents resistivity in Ohm-m. In the graphs, the black line represents the observed data, blue line represents the inverse model, and the red line represents the calculated response from the inverse model. (f) Interpreted resistivities and layer thicknesses for the five electrical soundings.

high resistivity (as high as $10^{5} \Omega-\mathrm{m}$ ) occurs. Such a highresistivity layer below a low-resistivity layer is also observed at Sounding P1S4; however, there it occurs at a much greater depth. The relative shallowness of this dry fourth layer at Sounding P1S5 is especially noteworthy juxtaposed with Sounding P1S3, which represents the deepest watersaturated layer of all five soundings. Even the shallowest depth estimate for this layer in Sounding P1S3 is considerably deeper than the high-resistivity layer in Sounding P1S5. An interpretation for this difference in models is interpreted to be the presence of a possible fault between Soundings P1S3 and P1S5 that may account for the relative displacement of rocks with varying properties (Figure 6). If such a fault acted as a barrier to groundwater flow, this interpretation could also offer an explanation for a high water level inferred in Sounding P1S5 relative to that at Sounding P1S3. A fault 


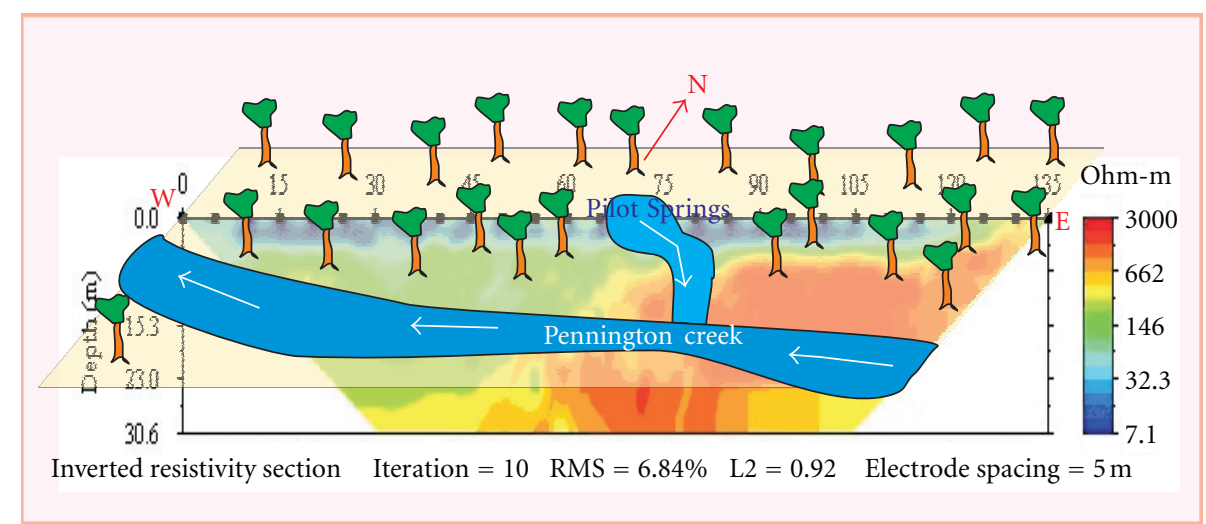

Figure 5: Location of Pilot Springs and Pennington Creek with respect to ERT profile CD. The orientation of the profile is W-E. Arrow marks shown in Pennington Creek and Pilot Springs indicate the direction of water flow.

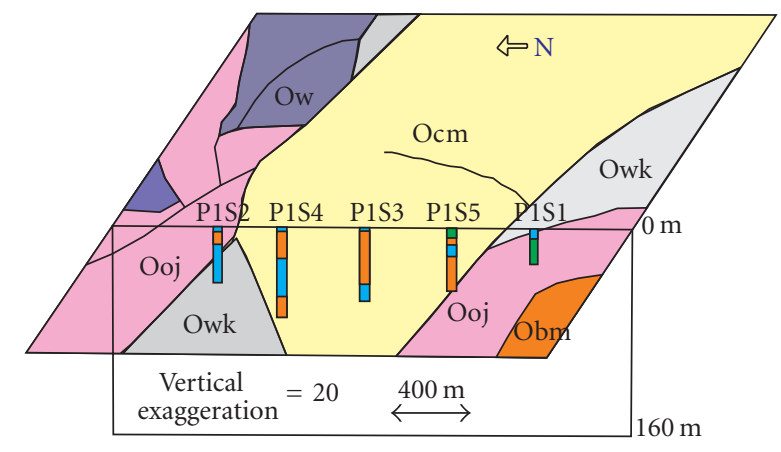

$20-200 \Omega \mathrm{m}$
$200-1000 \Omega \mathrm{m}$
$>1000 \Omega \mathrm{m}$

FIGURE 6: Diagram of subsurface resistivity model relative to surface geology. Cool Creek and McKenzie Hill Formations (Ocm), West Spring Creek and Kindblade Formations (Owk and Ow), Oil Creek Formation and Joins Formation (Ooj), and Bromide, Tulip Creek, and McLish Formations (Obm).

at this location is not indicated on the geologic map, but the resistivity data in this study raises the possibility that one may be present. Alternatively, this model difference may represent the presence of another type of discontinuity, such as a lithostratigraphic facies change.

Examining Soundings P1S5 and P1S1 to the south, data limitations prevent making a conclusive assessment of the interaction of groundwater with the southern bounding fault lying between them. While the penetration depth for Sounding P1S5 is estimated to be at least $46 \mathrm{~m}$, for Sounding P1S1 it is only $22 \mathrm{~m}$. In Sounding P1S5, the top of the lowresistivity layer interpreted as the saturation zone occurs at a depth of 11-12 m below the surface; a resistivity layer of $240-270 \Omega-\mathrm{m}$ is observed in Sounding P1S1, which likely represents water saturated layer. However, whether this layer can be correlated with the low resistivity layer of Sounding P1S5 as the top of the aquifer would require further data at this sounding point.

Analysis of the $1 \mathrm{D}$ sounding data resulted in a preliminary model of the subsurface fault geometry in depth as indicated in Figure 6. The northern-bounding fault (F1 in Figures 1(b) and 7) in this region is hypothesized to be a southward-dipping thrust fault; this northern fault and the fault north of that appear to define the boundary between the high-resistivity second layer and the watersaturated rocks below it. In this model, the northern faults in the study area are interpreted as south-dipping thrust faults. This interpretation has significant implications for the groundwater hydrology in this area. The south-dipping thrust fault may serve to isolate the deeper Simpson Group aquifer from the overlying Mill Creek block of the Arbuckle group, acting to confine this part of the aquifer.

4.2. Comparison of Sounding Results with Data from Groundwater Wells. To independently confirm this interpretation of groundwater level based on resistivity, water levels from monitored groundwater wells in the study area were examined; data for these wells were obtained from the Oklahoma Water Resources Board. Figure 1(b) displays the locations of groundwater wells.

The two northernmost wells, No. 94677 and No. 29279, are located in the Ooj Formation (Simpson Group). Recent 


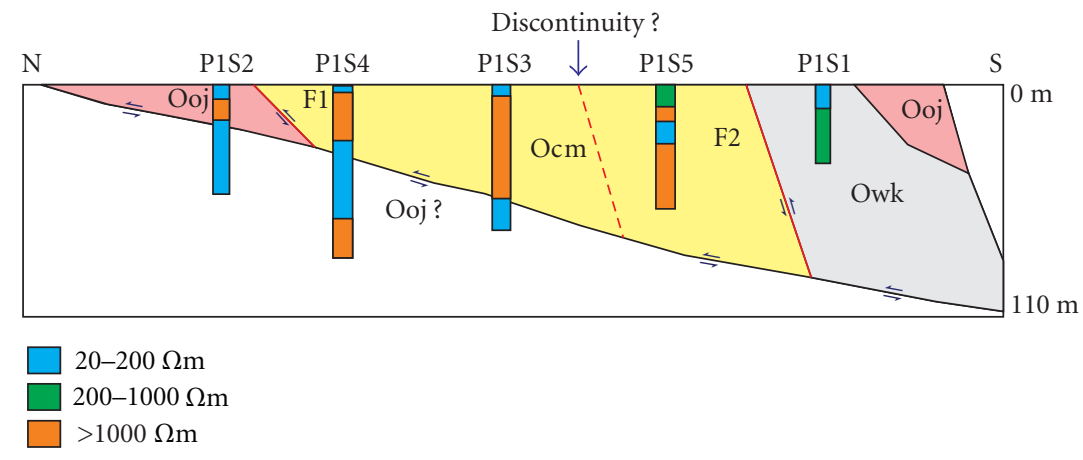

FIGURE 7: Interpreted fault geometry and subsurface geology along profile A-B relative to resistivity soundings.

water level information for well No. 29279 is not available, but the depth at which the driller first encountered water in the year 1991 was approximately $9.1 \mathrm{~m}$. Water depth at well No. 94677 was measured at $7.5 \mathrm{~m}$ in June 2005 and $8.7 \mathrm{~m}$ in June 2006. Although farther north than Sounding P1S2, these wells show a relatively shallow groundwater table in this area, consistent with the depth (7-14 $\mathrm{m})$ to the low-resistivity layer at this sounding.

To the south, Sounding P1S4 is located close to well No. 92340. The water level information available for this well is from February 2005; no water was encountered at a depth of approximately $13.1 \mathrm{~m}$. This is consistent with the low-resistivity layer of Sounding 4 occurring deeper than $12 \mathrm{~m}$. Well No. 92339 is located between Soundings P1S4 and P1S3 approximately a mile to the east. Here, water depth was measured at $25.8 \mathrm{~m}$ in June 2005 and $24.9 \mathrm{~m}$ in June 2006. Water depth at this well is shallower than the low-resistivity layer range offered for Sounding $3(35-55 \mathrm{~m})$, but it lies within the range of that of Sounding P1S4 (12$34 \mathrm{~m}$ ). Data from these two wells is thus consistent with the resistivity interpretations and confirms the trend found in the resistivity soundings of increasing aquifer depth toward the south.

Finally, the southernmost three wells lie in the Ooj Formation, west of Sounding P1S1. No recent water level data could be found for these wells; however, the water table measured at these wells in the 1970s was between 3 and $6 \mathrm{~m}$. Although this data is relatively old and must be used with caution, it is consistent with the interpretation at Sounding P1S1 of a very shallow low-resistivity layer.

Overall, the water table depths available from well data in the study area consistent with resistivity data [20]; this independent corroboration allows considerable confidence to be placed in the resistivity groundwater table interpretation.

4.3. ERT Data Analysis. In general, data collected using Wenner array provides resistivity control to intermediate depth range, has an intermediate resolution, and shows moderate sensitivity to near-surface lateral effects; dipoledipole array has the smallest depth of investigation range, highest resolution, and greatest sensitivity to near-surface lateral effects [21]. In addition, inverse modeling of ERT data from different electrode configurations leads to models that are dissimilar to some extent owing to the resolution, geometry, and noise tolerance characteristics of the electrode arrays. To see the difference in the final resistivity sections obtained from inversion of Wenner array, dipoledipole array and combined Wenner and dipole-dipole array data are shown along with sensitivity sections in Figure 8. The sensitivity values provides a measure of the amount of information offered by the resistivities of the model blocks [22]. Higher sensitivity values indicate reliable model resistivity. In general, the cells near the surface usually have higher sensitivity values because the sensitivity function has very large values near the electrodes. Also, inversion results of Wenner and dipole-dipole data results in dissimilar resistivity cross-sections due to their differing subsurface imaging capabilities [23]. Inversion of combined datasets of Wenner and dipole-dipole yield a more robust solution to subsurface resistivity distribution (Figure 8).

To address some of the issues mentioned above, data from both electrode arrays were inverted jointly to provide a smooth model. The resulting ERT images provide significant information about lateral resistivity variability close to Pilot Springs and Pennington Creek. ERT image of the northern profile located close to Pilot Springs (Profile CD) (Figure 9(a)) shows low-resistivity Arbuckle group rocks below Pilot springs. The low resistivity is inferred to be water-saturated rocks. ERT image acquired along a southern profile (Profile E-F) (Figure 9(b)) also indicates the presence of a fault contact and fluid filled fractures, similar to the resistivity cross-section obtained at Pilot Springs. It is inferred from the above ERT images that faults and fractures in the Arbuckle group rocks provide conduits for ground water to rise up from below.

In the area around Pilot Springs (Figure 5), Pennington Creek is observed with gas bubbles ascending to the surface in many places along the stream's course. Analysis of water samples taken at Pilot Springs and Pennington Creek in this area reveals a relatively low $\mathrm{pH}$, indicating that the water emanating from them is not in equilibrium with the greater carbonate reservoir, and instead implies a silicate source for this water. A possible hypothesis is that the source of this water is the silicate aquifer system to the north. Groundwater from this northern aquifer may flow south, encounter a fault 


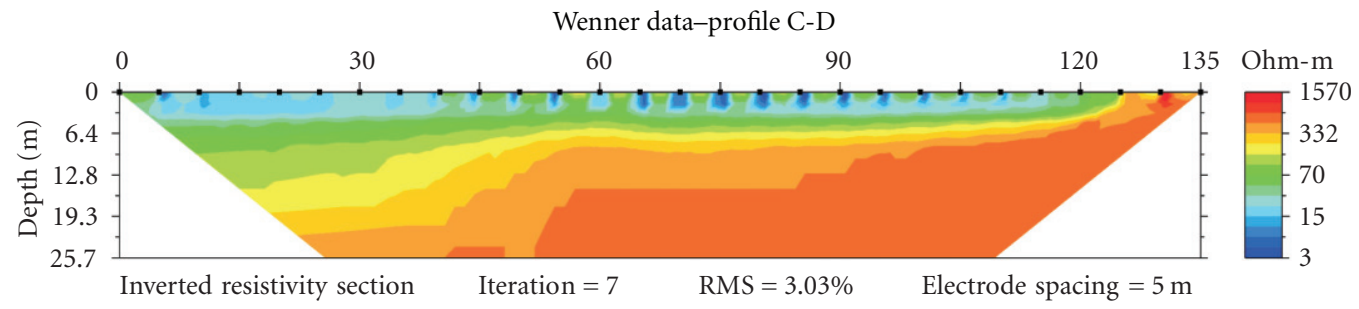

(a)

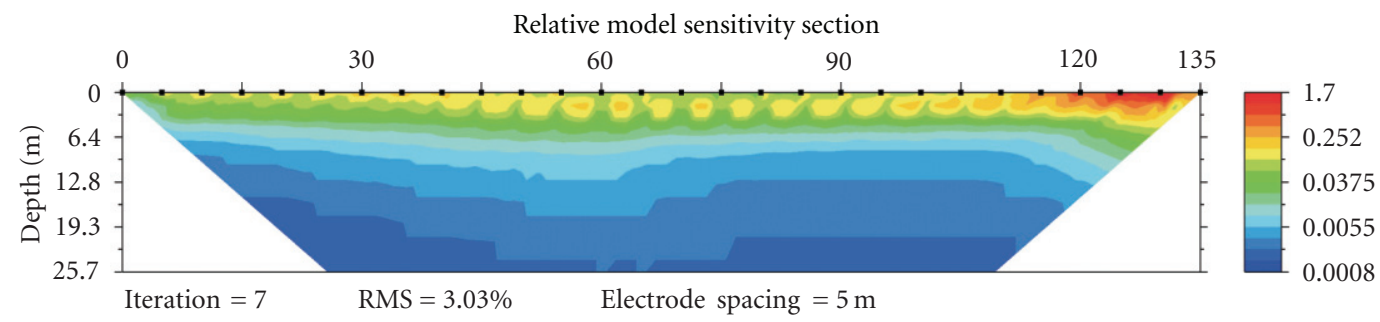

(b)

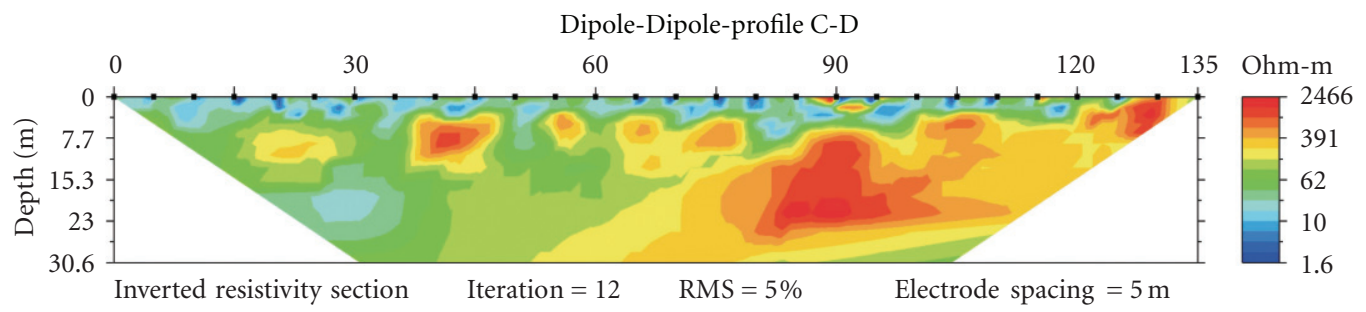

(c)

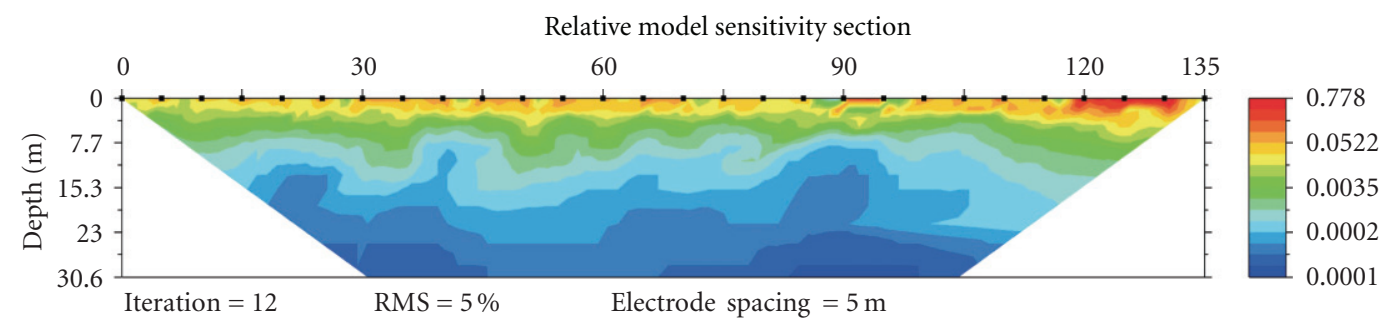

(d)

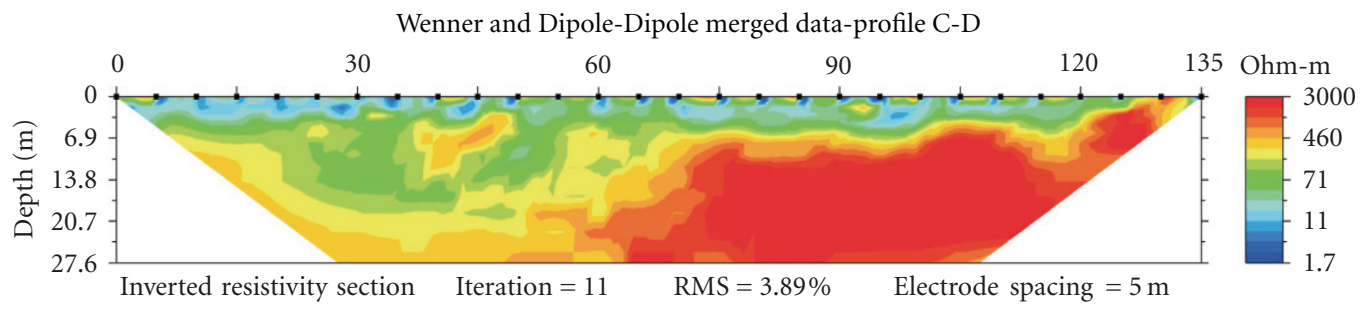

(e)

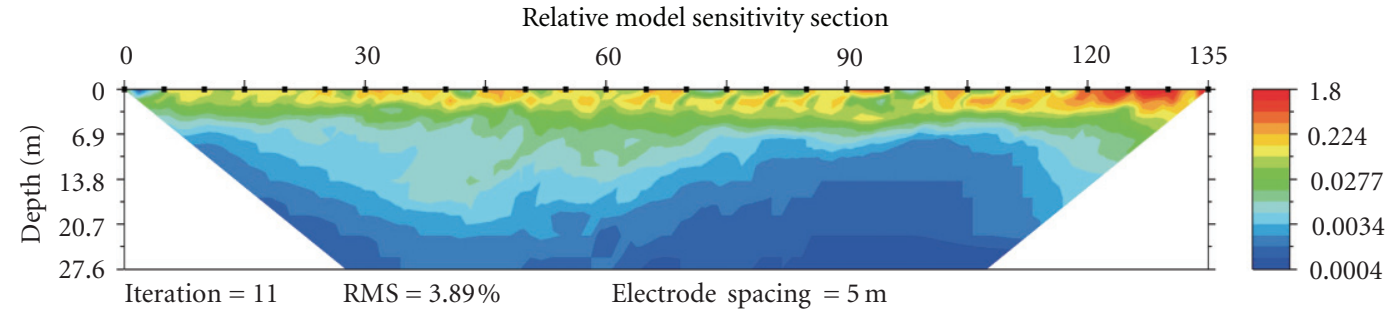

(f)

FIGURE 8: Resistivity sections constructed from Wenner, dipole-dipole, and merged Wenner and dipole-dipole data along with their corresponding sensitivity sections. 


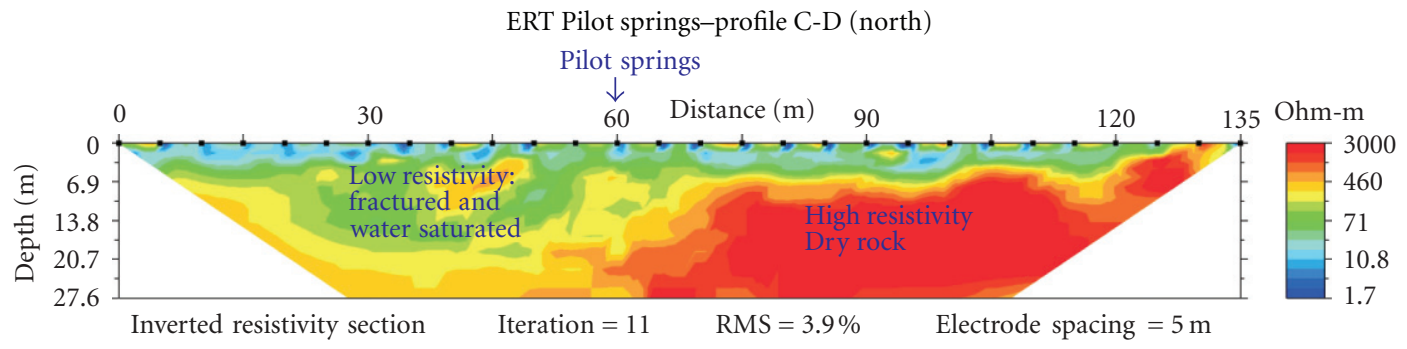

(a)

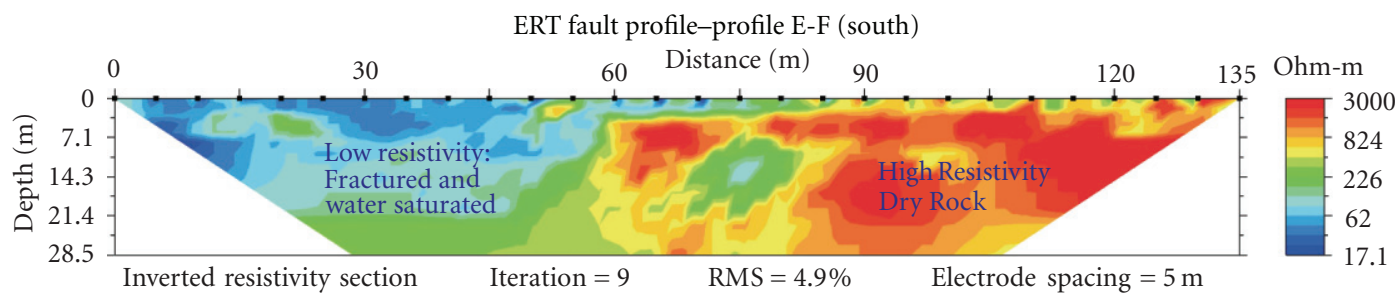

(b)

FIGURE 9: (a) ER tomography resistivity section close to Pilot Springs using Wenner and dipole-dipole arrays. (b) ER tomography resistivity section across mapped fault using Wenner and dipole-dipole arrays.

that acts as a baffle and redirects water upward, and emerge at the surface to create Pilot Springs and feed Pennington Creek.

\section{Conclusions}

Electrical resistivity surveys were carried out in the ArbuckleSimpson aquifer in Mill Creek Block to (1) understand how faults and fractures control groundwater flow in this area, and (2) delineate the geometry of the northern fault bounding the Mill Creek block. Five electrical resistivity soundings were carried out in the study area to achieve these goals. The resistivity data provides insight into both the hydrogeologic and the structural environment present in the study area of the aquifer. The trend of a deepening low-resistivity third layer from Sounding P1S2 in the north to Sounding P1S3 farther south likely reflects a deepening groundwater table, which is consistent with a south-dipping northern fault delineating the overlying Arbuckle Group formations from an underlying confined Simpson Group aquifer. Within this interpretation, the Mill Creek block is likely an isolated system, interacting with the northern silicate-based aquifer only through dissolution faults and fractures. Such features might allow water to ascend directly from the underlying aquifer to the surface, which could account for the presence of Pilot Springs and Pennington Creek and the properties of the water emanating from them, which imply a silicate rather than a carbonate source.

It is inferred from ERT image obtained at Pilot Springs (Figure 9(a)) that water saturated rock section lies in the shallow subsurface indicating a fractured rock strata through which deeper water is ascending and feeding Pilot Springs, which in turn flows into Pennington Creek. About half a kilometer south of Pilot Springs, the southern ERT profile
(Figure 9(b)) shows a low resistivity section that signifies fractured and water-filled rock section that is juxtaposed to a dry rock section. This section of low resistivities seems to correlate spatially with the low resistivity section observed at Pilot Springs to the north. If this interpretation is accepted, then this trend indicates a fracture system in extending the near surface from the northern profile to the southern profile.

From the analysis of 1D sounding data and 2D ERT data, we interpret the Mill Creek block of the Arbuckle-Simpson aquifer as an isolated system, interacting with the northern silicate-based aquifer only through dissolution faults and fractures. Such features might allow water to ascend directly from the underlying aquifer to the surface, which could account for the presence of Pilot Springs. Hence, if large amounts of water were to be pumped out of this aquifer block, it might lead to drying up of the streams in the area.

\section{References}

[1] H. Flathe, "Possibilities and limitations in applying geoelectrical methods to hydrogeological problems in coastal areas of north west Germany," Geophysical Prospecting, vol. 3, pp. 95$110,1955$.

[2] A. A. R. Zohdy, "The use of schlumberger and equatorial soundings in groundwater investigations near el paso, texas," Geophysics, vol. 34, no. 5, pp. 713-728, 1969.

[3] H. Flathe, "Interpretation of geoelectircal rsistivity measuremnts for solving hydrogeological problems," in Mining and Groundwater Geophysics: Geological Survey of Canada Economic Geologica Report, no. 26, E. W. Morely, Ed., pp. 580597, 1970.

[4] A. A. Ogilvy, "Geophysical prospecting for groundwater in the Soviet Union," in Mining and Groundwater Geophysics: Geological Survey of Canada Economic Geological Report, no. 26, E. W. Morely, Ed., pp. 536-543, 1970. 
[5] A. A. R. Zohdy, G. P. Eaton, and D. R. Mabey, Application of Surface Geoophysics to Ground Water Investigation, U. S. G. S. Techniques of Water-Resource Investigation, 1974.

[6] S. Beeson and C. R. C. Jones, "The combined EMT/VES geophysical method of siting boreholes," Ground Water, vol. 26, no. 1, pp. 54-63, 1988.

[7] A. Olayinka and R. Barker, "Borehole siting in crystalline basement areas of Nigeria with a microprocessor-controlled resistivity traversing system," Ground Water, vol. 28, no. 2, pp. 178-183, 1990.

[8] J. R. T. Hazell, C. R. Cratchley, and A. M. Preston, "The location of aquifers in crystalline rocks and alluvium in Northern Nigeria using combined electromagnetic and resistivity techniques," Quarterly Journal of Engineering Geology, vol. 21, no. 2, pp. 159-175, 1988.

[9] J. R. T. Hazell, C. R. Cratchley, and C. R. C. Jones, "The hydrogeology of crystalline aquifers in northern. Nigeria and geophysical techniques used in their exploration," in The Hydrogeology of Crystalline Basement Aquifers in Africa. Geological Society Special Publication, no. 66, E. P. Wight and W. G. Burgess, Eds., pp. 155-182, 1992.

[10] R. D. Barker, "The offset system of electrical resistivity sounding and its use with a multicore cable," Geophysical Prospecting, vol. 29, no. 1, pp. 128-143, 1992.

[11] R. M. Carruthers and I. F. Smith, "The use of ground electrical methods for siting water supply boreholes in shallow crystalline basement terrains," in The Hydrogeology of Crystalline Basement Aquifers in Africa. Geological Society Special Publication, no. 66, E. P. Wight and W. G. Burgess, Eds., pp. 203-220, 1992.

[12] R. D. Barker, "Application of electrical tomography in groundwater contamination studies: 61st Mtg. Eur. Assoc. Expl Geophys," Extended Abstracts, European Association of Geophysical Exploration, Session:P082, 1996.

[13] W. E. Ham, M. E. McKinley et al., "Geologic map and sections of the Arbuckle Mountains, Oklahoma, Plate 1," in Hydrology of the Arbuckle Mountains Area, South-Central Oklahoma: Oklahoma Geological Survey Circular 91, K. S. Johnson, Ed., 1990.

[14] R. O. Fay, Geology of the Arbuckle Mountains along Interstate 35, Carter and Murray Counties, Oklahoma: Oklahoma Geological Survey Guidebook 26, 1989.

[15] R. W. Fairchild, R. L. Hanson, and R. E. Davis, Hydrology of the Arbuckle Mountains area, south-central Oklahoma: Oklahoma Geological Survey Circular 91, 1990.

[16] D. S. Scheirer and H. S. Alegra, "Gravity investigations of the Chickasaw National Recreation Area, south-central Oklahoma," USGS Open-File Report 2006-1083, 2006.

[17] J. Puckette, T. Halihan, and F. Faith,, "Characterization of the Arbuckle-Simpson Aquifer," Report for the Arbuckle-Simpson Hydrology Study, The Oklahoma Water Resources Board, 2009.

[18] W. M. Telford, L. P. Geldart, R. E. Sheriff, and D. A. Keys, Applied Geophysics, Cambridge University Press, 1976.

[19] K. Ramachandran, T. Bryan, R. Tayler, and L. Erin, "Characterizing the Arbuckle-Simpson aquifer through electrical methods," SEG Technical Program Expanded Abstracts, vol. 29, no. 1, pp. 2014-2018, 2010.

[20] E. Lewallen, Geophysical investigation of the arbuckle-simpson aquifer, Southern Oklahoma, M.S. thesis, The University of Tulsa, 2008.

[21] R. Barker and J. Moore, "The application of time-lapse electrical tomography in groundwater studies," The Leading Edge, vol. 17, no. 10, pp. 1454-1458, 1998.
[22] M. H. Loke and R. D. Barker, "Rapid least-squares inversion of apparent resistivity pseudosections by a quasi-Newton method," Geophysical Prospecting, vol. 44, no. 1, pp. 131-152, 1996.

[23] Loke M.H., "Tutorial: 2-D and 3-D electrical imaging surveys," course notes, http://www.geoelectrical.com/coursenotes.zip. 

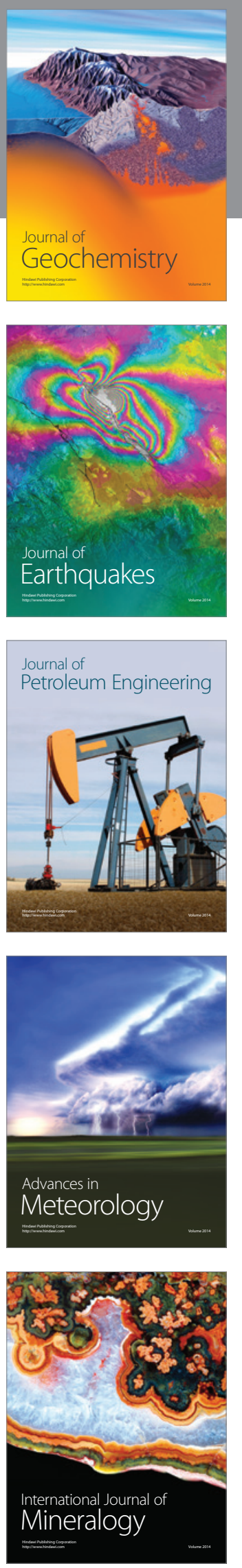
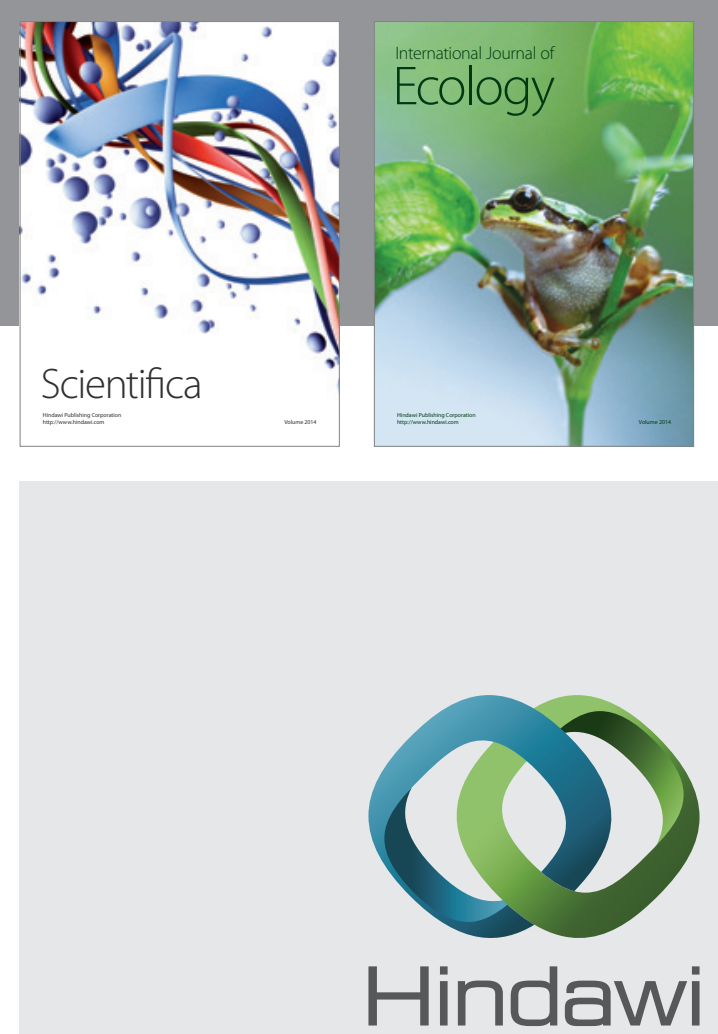

Submit your manuscripts at http://www.hindawi.com
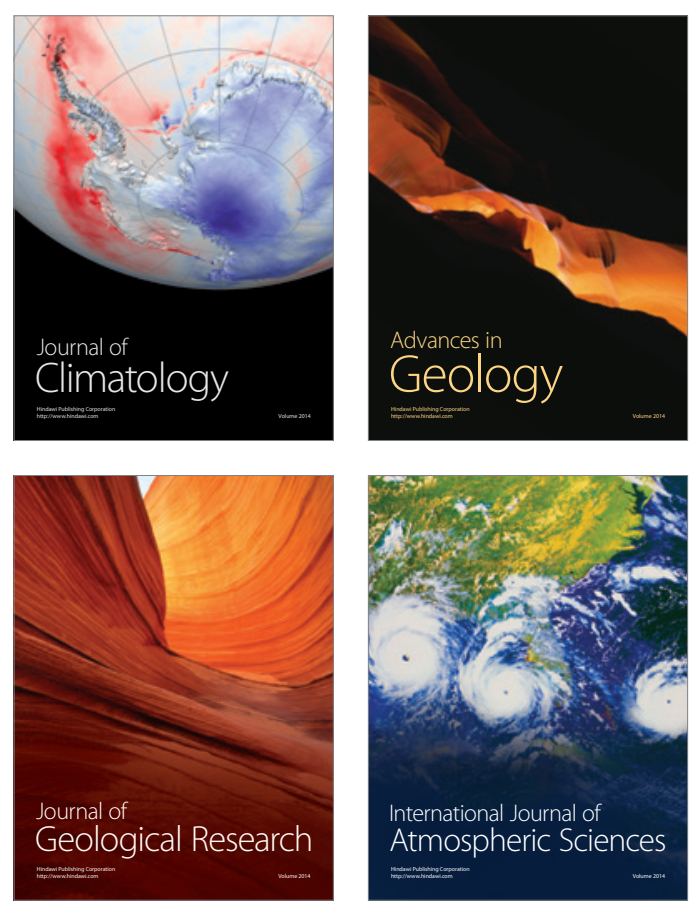
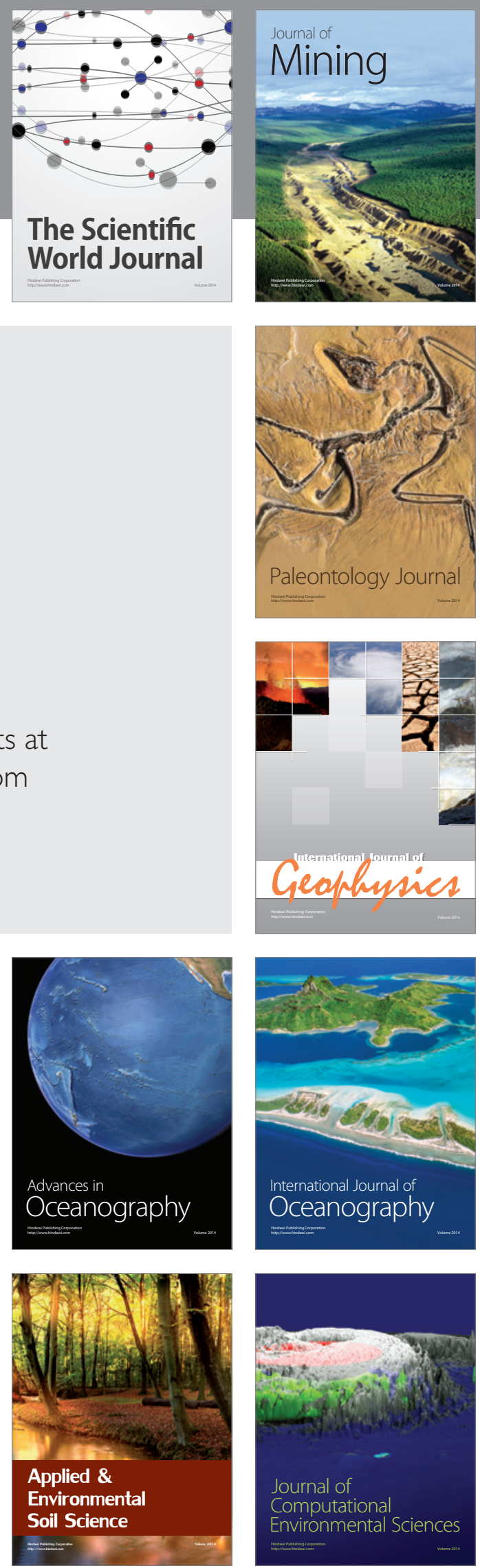